\title{
Induction of junB Expression, but Not c-jun, by Granulocyte Colony-stimulating Factor or Macrophage Colony-stimulating Factor in the Proliferative Response of Human Myeloid Leukemia Cells
}

Koichi Adachi and Hidehiko Saito

Division of Hematology/Oncology, First Department of Internal Medicine, Nagoya University School of Medicine, Nagoya 466, Japan

\section{Abstract}

The proliferative effects of granulocyte colony-stimulating factor (G-CSF) and macrophage colony-stimulating factor (MCSF) on human hematopoietic cells have been reported, but the intranuclear mechanism of early signal response to these mitogenic stimuli remains unknown. Using an established human myeloid leukemia cell line (NKM-1) which can grow in serumfree medium in response to G-CSF or M-CSF, we examined expressions of the jun family genes, c-jun, junB, and junD, which are coexpressed by various growth factors in many tissues. In parallel with regrowth from the $G_{0} / G_{1}$ resting state by addition of recombinant human G-CSF or M-CSF after serum deprivation, NKM-1 cells showed the transient expression of the junB gene with a peak of ninefold above the basal level between 40 and $60 \mathrm{~min}$. In contrast, c-jun expression was not stimulated by these CSFs. JunD expression was constitutively observed at detectable levels. Furthermore, c-fos mRNA was rapidly induced to a peak of 14-fold after CSF stimulation. Transcriptional run-on assays revealed that treatment of serum-starved NKM-1 with $50 \mathrm{ng} / \mathrm{ml}$ G-CSF or M-CSF increased the transcription rate of the junB gene and the $c-f o s$ gene by 1.8-fold and 2.9-fold, respectively, but did not induce any transcript of the c-jun gene. The results indicate that the expression of the junB and c-fos genes is activated, at least in part, at the transcriptional level in response to these CSFs. These findings suggest that the signal activating c-jun expression might not be involved in the proliferative action of G-CSF and M-CSF but junB may be one of important elements in early response events of the signal transduction system in human CSF-responsive hematopoietic cells. (J. Clin. Invest. 1992. 89:1657-1661.) Key words: hematopoietic growth factors $\bullet$ immediate early genes $\bullet$ jun family genes $\bullet$ transcriptional activation • signal transduction

Address correspondence to Dr. Koichi Adachi, Division of Hematology/Oncology, First Department of Internal Medicine, Nagoya University School of Medicine, 65 Tsurumai, Showa, Nagoya 466, Japan.

Received for publication 10 October 1991 and in revised form 9 December 1991

J. Clin. Invest.

(c) The American Society for Clinical Investigation, Inc. $0021-9738 / 92 / 05 / 1657 / 05 \$ 2.00$

Volume 89, May 1992, 1657-1661

\section{Introduction}

Granulocyte colony-stimulating factor (G-CSF) ${ }^{1}$ and macrophage colony-stimulating factor (M-CSF) are members of hematopoietic growth factors for granulocytic cell lineage and monocytic cell lineage, respectively, which are clinically available for patients with leukopenia as recombinant human CSFs. There have been some reports about the proliferative effects of these CSFs on human hematopoietic cells $(1,2)$, but the intranuclear mechanism of early signal response to these mitogenic stimuli remains unknown. Each CSF binds to its specific receptor on the surface of hematopoietic cells $(3,4)$. The CSF-receptor interaction triggers a complex and poorly understood cascade of molecular events in signal transduction pathways, eventually leading to the transcriptional activation of immediate early response genes within the nucleus.

A series of studies indicate that many of the protooncogeneencoded products play pivotal roles in signal transduction systems that regulate cell proliferation in response to growth factors (5-7). Among these growth-related genes, some immediate early response genes such as members of the jun family or the fos family have been recently shown to be transiently activated when quiescent cells are stimulated by serum or various growth factors (8-12). C-jun, junB, and junD which share significant sequence homology are coexpressed in many tissues (13-17), although the transcription of c-jun and junB may reveal different responses between various mitogenic stimuli and cell types $(18,19)$. Recent studies indicated that these genes are not coordinately regulated in fibroblasts $(20)$ and that junB functions as a negative regulator of genes activated by c-jun $(20,21)$. These findings may suggest that each product of the c-jun and junB genes confers distinct regulation on different target genes.

Little is known about the response of the jun family genes to G-CSF or M-CSF in cellular proliferation. To investigate the molecular mechanism of proliferative action of G-CSF and M-CSF in human hematopoietic cells, we employed the human myeloid leukemia cells (NKM-1) coexpressing both distinct G-CSF receptors and M-CSF receptors in this study. It was previously shown that NKM-1 cells can proliferate in serum-free medium in response to the physiological concentration of recombinant human G-CSF or M-CSF in a dose-dependent manner, and also additively to both CSFs $(22,23)$. We report that G-CSF and M-CSF induce junB transcripts, but not

1. Abbreviations used in this paper: CSF, colony-stimulating factor; FBS, fetal bovine serum; G-CSF, granulocyte CSF; M-CSF, macrophage CSF; MTT, tetrazolium salt. 
c-jun, in the proliferative stimulation of human CSF-responsive myeloid cells.

\section{Methods}

Cell culture. Human myeloid leukemia cells (NKM-1) were grown in RPMI 1640 medium (Gibco Laboratories, Grand Island, NY) supplemented with $10 \%$ fetal bovine serum (FBS) (Flow Laboratories, Stanmore, Australia), $100 \mathrm{U} / \mathrm{ml}$ penicillin, and $50 \mu \mathrm{g} / \mathrm{ml}$ streptomycin in $5 \% \mathrm{CO}_{2}$ humidified atmosphere at $37^{\circ} \mathrm{C}$. After serum-deprived culture, NKM-1 cells were incubated in RPMI 1640 containing $10 \mu \mathrm{g} / \mathrm{ml} \mathrm{hu-}$ man transferrin with either G-CSF, M-CSF, or FBS. No feature of cell differentiation can be induced by G-CSF or M-CSF in these cells (22). Flow cytometric analysis of the cell cycle based on DNA content was performed after propidium iodide (Sigma Chemical Co., St. Louis, MO) staining as described previously (22). The nuclei were analyzed by Epics Profile flow cytometry (Coulter Electronics Inc., Hialeah, FL). The percentage of cells in each phase of the cell cycle was estimated by a program developed by Ortho Diagnostics (Westwood, MA). The viable cells plated in flat-bottomed 96 -microwell plates were quantitated by a colorimetric assay using tetrazolium salt, MTT, as described (24). The plates were read on a scanning multiwell spectrophotometer, SLT210, (SLT-LAB Instruments, Salzburg, Austria) using a test wavelength of $545 \mathrm{~nm}$ and a reference wavelength of $650 \mathrm{~nm}$. DNA synthesis of cells seeded in 96 -well microplates was determined by measuring $\left[{ }^{3} \mathrm{H}\right]-$ thymidine uptake. After $20 \mathrm{~h}$ of incubation at $37^{\circ} \mathrm{C}, 0.2 \mu \mathrm{Ci}$ of $\left[{ }^{3} \mathrm{H}\right]-$ thymidine $(6.7 \mathrm{Ci} / \mathrm{mmol})$ was added per well. $5 \mathrm{~h}$ later the cells were harvested using a Titertek harvester 550 (Flow Laboratories, McLean, VA), and the uptake of $\left[{ }^{3} \mathrm{H}\right]$ thymidine was assessed with a scintillation counter (LS 5000; Beckman Instruménts, Inc., Fullerton, CA). Recombinant human G-CSF (KRN8601) and M-CSF were provided from Kirin Brewery Co. (Shibuya, Tokyo) and Morinaga Milk Industry Co. (Minato, Tokyo), respectively.

$R N A$ preparation and Northern blot analysis. Total cellular RNA samples were prepared by the guanidine isothiocyanate-cesium chloride technique (25) at the indicated times. Each $15 \mu \mathrm{g}$ of RNA samples was electrophoresed on a $1.2 \%$ formaldehyde-agarose gel and transferred to Hybond-N membrane (Amersham Corp., Arlington Heights, IL). Prehybridizations, hybridizations, and washings were carried out according to the manufacturer's manual. ${ }^{32} \mathrm{P}$-oligo-random-labeled probes used were the 1.8-kb BamHI/EcoRI fragment of a human c-jun cDNA (10) (provided by Dr. R. Tjian, University of California, Berkeley), the $0.45-\mathrm{kb}$ Narl fragment of a human junB cDNA (21) (provided by Dr. J. Minna, National Cancer Institute, Bethesda, MD), the 1.8-kb EcoRI fragment of a human junD cDNA (17) (provided by Dr. N. Nomura, Nippon Medical School, Kawasaki, Japan), the 2.1-kb EcoRI fragment of a human c-fos cDNA (provided from Japanese Cancer Research Resources Bank, Shinagawa, Tokyo), and the 1.4-kb PstI fragment of a human HLA-B7 cDNA (provided from Japanese Cancer Research Resources Bank). The same membranes were repeatedly rehybridized for each probe after being boiled in $0.1 \%$ SDS buffer. The autoradiograms were scanned using a Fuji x-ray densitometer, model
A

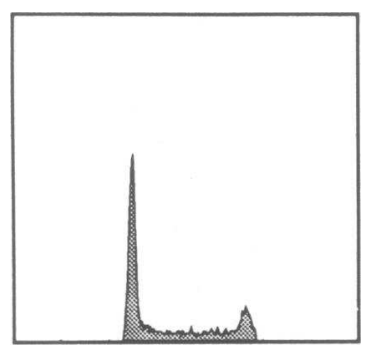

exponentially growing cells

\begin{tabular}{lc}
\hline \multicolumn{1}{c}{ phase } & $\%$ \\
\hline$G_{0}-G_{1}$ & 44.7 \\
$S\left(G_{0} / G_{1}-G_{2} / M\right)$ & 44.5 \\
$G_{2}-M$ & 10.8 \\
\hline
\end{tabular}

B

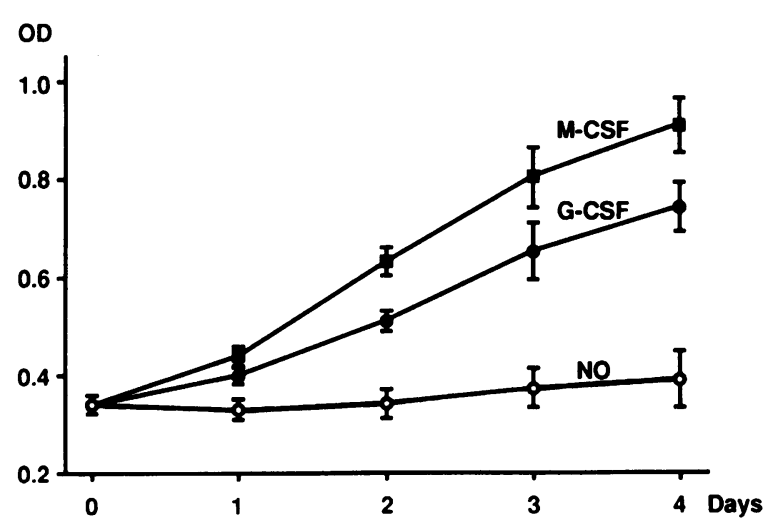

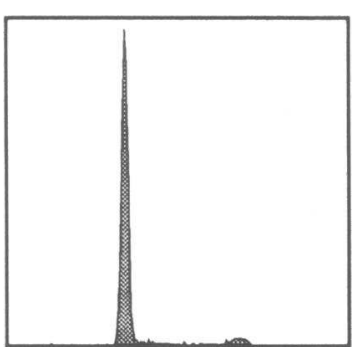

resting cells $48 \mathrm{~h}$ after serum deprivation

\begin{tabular}{lc}
\hline \multicolumn{1}{c}{ phase } & $\%$ \\
\hline $\mathrm{G}_{0}-\mathrm{G}_{1}$ & 78.6 \\
$\mathrm{~S}\left(\mathrm{G}_{0} / \mathrm{G}_{1}-\mathrm{G}_{2} / \mathrm{M}\right)$ & 17.5 \\
$\mathrm{G}_{2}-\mathrm{M}$ & 3.9
\end{tabular}

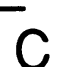

$\times 10$

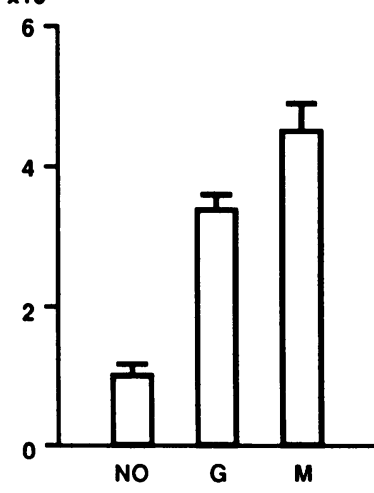

Figure 1. Growth-stimulatory effects of G-CSF or M-CSF on NKM-1 cells. $(A)$ Flow cytometric analysis of the cell cycle based on DNA content. Left to right, profile of exponentially growing NKM-1 cells in RPMI 1640 medium supplemented with $10 \%$ FBS; resting cells after 48 $\mathrm{h}$ of serum deprivation; regrowing cells in the medium containing 10 $\mu \mathrm{g} / \mathrm{ml}$ human transferrin after 24 $\mathrm{h}$ of $10 \mathrm{ng} / \mathrm{ml} \mathrm{G-CSF}$ addition, respectively. Vertical scale, relative number of cells; horizontal scale, relative DNA content by fluorescence intensity. The percentage of cells in $G_{0} / G_{1}, S$, and $G_{2} / M$ is shown below each figure. $(B)$ Cell growth curves of NKM- 1 cells by the MTT assay. The cells $\left(2 \times 10^{4} /\right.$ well) were cultured in serum-free RPMI 1640 containing only transferrin for $4 \mathrm{~d}$ with either $10 \mathrm{ng} / \mathrm{ml}$ G-CSF (๑), $10 \mathrm{ng} / \mathrm{ml} \mathrm{M-CSF} \mathrm{( \bullet ),} \mathrm{or}$ without CSF (o). The data were expressed as a fraction of absorbance and shown as the mean $\pm \mathrm{SD}$ in triplicate culture. The results with the MTT assay were consistently equivalent with the viable cell counts by the trypan blue exclusion method. (C) $\left[{ }^{3} \mathrm{H}\right]$ thymidine incorporation assay for DNA synthesis. As described in $A$ and $B$, after serum starvation, the cells $\left(2 \times 10^{4} /\right.$ well $)$ were cultured with or without CSF. After $20 \mathrm{~h}$ of incubation, the cells were grown with $\left[{ }^{3} \mathrm{H}\right]$ thymidine for $5 \mathrm{~h}$ and harvested. The values shown represent the
minute \pm SD of triplicate culture; NO, without CSF; $G$, with $10 \mathrm{ng} / \mathrm{ml} \mathrm{G-CSF} ; M$, with $10 \mathrm{ng} / \mathrm{ml}$ M-CSF; bars, \pm SD. 
301 (Fuji Film Co., Tokyo). The intensity of mRNA bands estimated was normalized against HLA-B transcripts of an internal control.

Nuclear run-on assays. Nuclei isolation and run-on transcription were carried out as described previously (8). The ${ }^{32} \mathrm{P}$-labeled RNA was isolated by the method of acid guanidinium thiocyanate-phenol-chloroform extraction (26) with minor modifications. The labelled RNA (4 $\times 10^{6} \mathrm{cpm}$ ) was hybridized in $2 \mathrm{ml}$ of $40 \%$ formamide, $5 \times$ Denhardt's solution, $4 \times$ standard saline citrate (SSC), $0.4 \%$ SDS, 5 mM EDTA, and $100 \mu \mathrm{g} / \mathrm{ml} \mathrm{tRNA}$ at $42^{\circ} \mathrm{C}$ for $72 \mathrm{~h}$ to cDNA fragments blotted on Hybond-N membrane by Southern method. The blots were washed

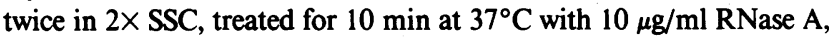
washed for $1 \mathrm{~h}$ at $42^{\circ} \mathrm{C}$ in $0.1 \% \mathrm{SSC}, 0.1 \% \mathrm{SDS}$, and exposed to $\mathrm{x}$-ray films for $2 \mathrm{~d}$. The intensity of hybridized transcripts quantitated in autoradiography was normalized against the HLA-B internal control.

\section{Results}

We employed the human myeloid leukemia cells, NKM-1, with both G-CSF and M-CSF receptors as a model of human CSF-responsive cells. NKM-1 cells were maintained in RPMI 1640 medium supplemented with $10 \%$ FBS and were made quiescent by deprivation of FBS. Flow cytometric assays showed that quiescent population in the $G_{0} / G_{1}$ resting phase of the cell cycle increased from 44.7 to $78.6 \%$ after $48 \mathrm{~h}$ of incubation in the serum-deprived condition. The resting cells, then, resumed their cycle through $G_{1}$ into $S$ phase after stimulating this serum-deprived culture with $10 \mathrm{ng} / \mathrm{ml}$ of G-CSF for an additional $24 \mathrm{~h}$ (Fig. $1 \mathrm{~A}$ ). Growth response curves using the MTT assay showed that the number of viable cells in serumfree RPMI 1640 containing $10 \mu \mathrm{g} / \mathrm{ml}$ transferrin was progressively increasing for $4 \mathrm{~d}$ after G-CSF or M-CSF addition (Fig. 1 $B)$. These proliferative responses to CSFs were also demonstrated by $\left[{ }^{3} \mathrm{H}\right]$ thymidine incorporation. DNA synthesis was significantly increased after $24 \mathrm{~h}$ exposure to G-CSF or M-CSF (Fig. 1C).

Treatment of quiescent, serum-starved NKM-1 cells with $50 \mathrm{ng} / \mathrm{ml} \mathrm{G-CSF}$ or M-CSF resulted in a rapid, transient increase in the levels of junB mRNA and c-fos mRNA. As shown in Fig. 2, Northern blot analysis reveals that the increase of junB mRNA occurred within 20 min of CSF stimulation and reached a peak of ninefold between 40 and $60 \mathrm{~min}$, and declined gradually to the basal level of untreated cells. In contrast, c-jun exhibited little change above the basal level for several hours after CSF addition. JunD expression was constitutively observed at detectable levels even in the quiescent state and anytime after CSF stimulation. The protein products of the jun family genes form heterodimetric complexes with fos protein to make a higher DNA binding affinity (27-29). Although c-fos mRNA was also present at low levels in untreated NKM-1 cells, it was rapidly induced and elevated to a peak of 14-fold between 20 and $40 \mathrm{~min}$ after CSF stimulation. The results of these gene responses were similar to those in both cases of G$\mathrm{CSF}$ and M-CSF. In contrast, the stimulation of quiescent cells with $10 \%$ FBS induced the activated expression of c-jun by sevenfold, in addition to the similar enhancement of junB and c-fos expression (Fig. 2). This demonstrates that the mechanism of c-jun gene expression is not defective in NKM-1 cells and that the signal transduction systems to nuclear transcription factors are different between CSF and FBS stimuli. When exponentially proliferating cells in the medium containing $10 \%$ FBS were treated with G-CSF, no induction in c-jun, junB, and c-fos mRNAs was observed.

Transcriptional run-on assays in isolated nuclei from NKM-1 cells revealed the mechanism responsible for the induction of the junB gene expression by CSFs. Fig. 3 shows that

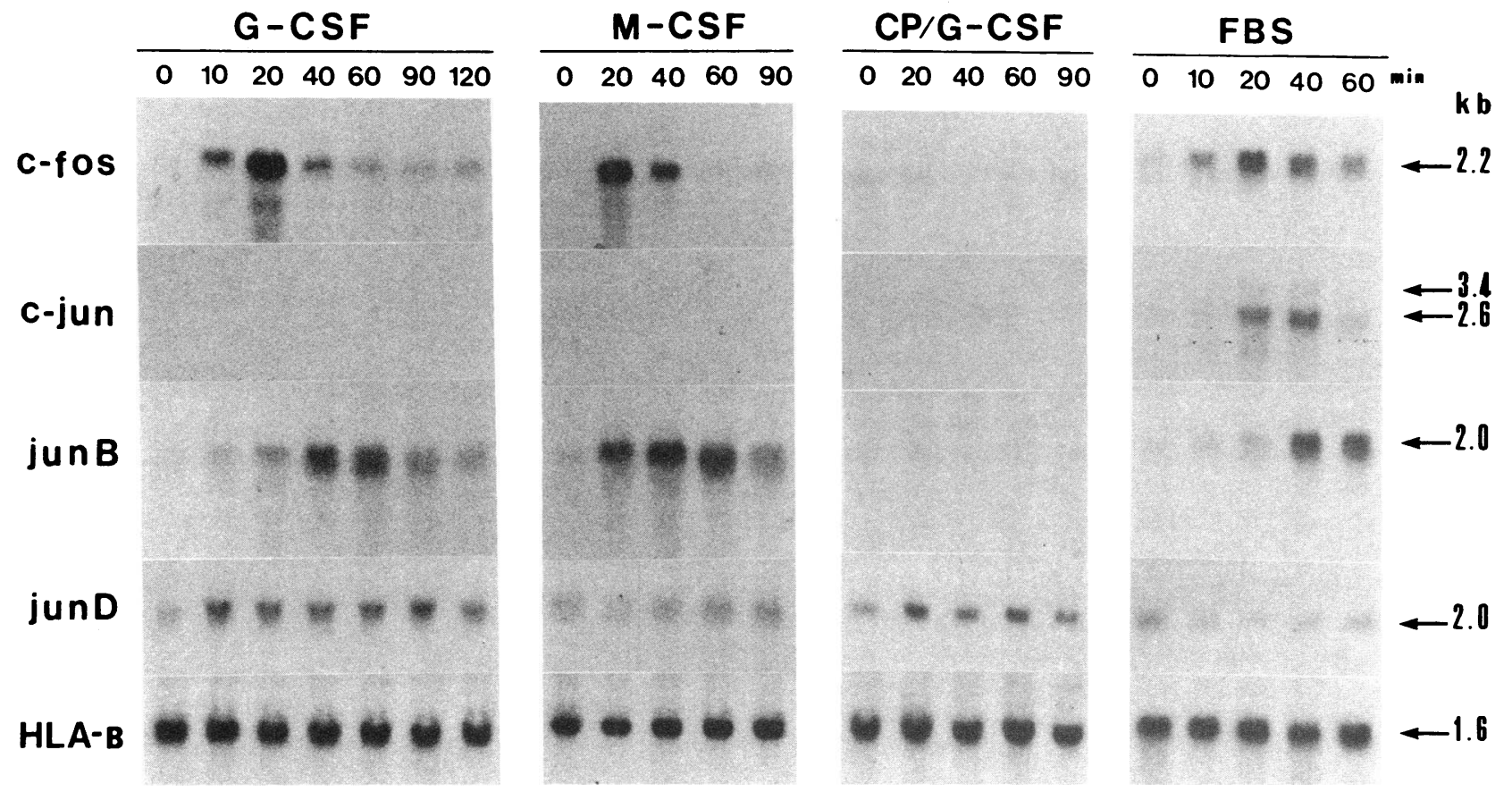

Figure 2. Northern blot analysis of expressions of the jun family genes and the c-fos gene after stimulation of NKM-1 cells with G-CSF, M-CSF, or FBS. After $48 \mathrm{~h}$ of serum deprivation, NKM-1 cells were treated with either $50 \mathrm{ng} / \mathrm{ml} \mathrm{G-CSF}, 50 \mathrm{ng} / \mathrm{ml} \mathrm{M-CSF}$, or $10 \%$ FBS for the indicated times. In G-CSF/CP, $50 \mathrm{ng} / \mathrm{ml}$ G-CSF were added to continuously proliferating NKM-1 cells in 10\% FBS-containing RPMI 1640 medium. Total cellular RNA ( $15 \mu \mathrm{g} /$ lane) was hybridized to each ${ }^{32} \mathrm{P}$-labeled probe of $\mathrm{c}-f o s$, c-jun, junB, junD, or HLA-B7 cDNA. HLA-B expression was used as an internal control. 


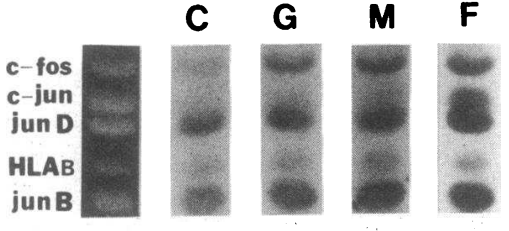

Figure 3. Transcription run-on assay of the jun family genes and the cfos gene after stimulation of NKM-1 cells with G-CSF, M-CSF, or FBS. The cells were prepared and treated as described in Fig. 2. Nuclei $\left(2 \times 10^{7}\right)$ were isolated from control untreated NKM-1 cells $(C)$ or from cells treated for 30 min with G-CSF $(G), \mathrm{M}-\mathrm{CSF}(M)$, or $\mathrm{FBS}(F)$. The left picture indicates the position of each cDNA fragment $(2.10 \mathrm{~kb}$ c-fos, $1.96 \mathrm{~kb}$ c-jun, $1.80 \mathrm{~kb}$ junD, $1.40 \mathrm{~kb}$ HLA-B, $1.20 \mathrm{~kb}$ junB) stained by ethidium bromide before Southern blotting.

treatment of serum-starved NKM- 1 cells with $50 \mathrm{ng} / \mathrm{ml} \mathrm{G-CSF}$ or M-CSF increased the transcription rate of the junB gene and the c-fos gene by 1.8 -fold and 2.9-fold, respectively, but did not induce any transcript of the c-jun gene. There was a little enhancement on junD transcripts. These findings indicate that CSFs induce junB and c-fos expression, at least in part, by a transcriptional mechanism. In contrast, the transcription of the c-jun gene was activated by stimulation of $10 \%$ FBS with induction of junB and c-fos transcripts.

\section{Discussion}

The recent availability of cloned DNA probes for a variety of cellular response genes has made it possible to examine the transcriptional events resulting from growth factor stimulation. Immediate early response genes such as members of the jun family or the fos family have been reported to be induced in different cell types by serum or a variety of growth factors (820). There is, however, little known about the regulation of these genes by hematopoietic colony-stimulating factors, GCSF and M-CSF, since there have been very few human hematopoietic cell lines which can proliferate in response to these CSFs.

A recent report indicated that M-CSF induced c-jun expression with prolonged expression of the junB gene in human monocytes, but the induction of both c-jun and junB was associated with activation to a more differentiated monocytic phenotype (19). It suggests that both c-jun and junB expressions similar to those in other models of monocytic differentiation by chemical agents (30) should be definitely distinct from junB expression without c-jun in M-CSF-stimulated proliferation. Another reported that in the mouse 3T 3 cells transformed by a human CSF-1 receptor (c-fms) mutant gene, the expression of junB was induced after M-CSF stimulation but no mitogenic response was observed (31). It appears that the signal transduction system of mitogenic response through receptors to nuclear transcription factors should be very complex and concerted. Even though junB is activated, cells could not proliferate when another component of the responsive orchestration in the signal transduction system was dysfunctional because of the mutation of receptors (32).

It was recently reported that all three of anti-jun family antibodies prevented serum-stimulated DNA synthesis in 3T3 fibroblasts (33). In our experiment using an established human myeloid leukemia cell line, NKM-1, which can proliferate in response to G-CSF or M-CSF, the proliferative stimulation of NKM-1 cells with these CSFs was in parallel with the induction of junB transcripts, but the expression of c-jun mRNA was not identified at least for several hours after CSFs addition. The evidence that the stimulation of quiescent NKM-1 cells with FBS activated c-jun expression indicates that the signal transduction system to the c-jun gene and the mechanism of c-jun expression are not impaired in these cells. It suggests that the signals of serum stimulation are pleiotropic and different from the proliferative signals of purified recombinant G-CSF or MCSF. A second peak of c-jun expressed at the $G_{1} / S$ border in human fibroblasts (34) has not been determined in NKM-1 cells stimulated by CSFs, but it was reported to be different from response to receptor-generated signal and coupled to the time of entry to $S$ phase. These results suggest that the receptorgenerated signal activating c-jun expression might be not required for the proliferative action of G-CSF and M-CSF and that junB may be not sufficient but involved in the mechanism of hematopoietic cell proliferation by these CSFs. These findings will provide a basis for investigating the molecular mechanism of action of G-CSF and M-CSF in human hematopoietic cells. Further investigation is needed concerning what role the products of the jun genes play in mediating the action of GCSF and M-CSF and in stimulating the cellular proliferation.

\section{Acknowledgments}

We thank Dr. R. Tjian, Dr. J. Minna, and Dr. N. Nomura for providing the plasmids of c-jun CDNA, junB cDNA, and junD cDNA, respectively.

This work was supported in part by the fund of Aichi Blood Disease Research Foundation.

\section{References}

1. Sachs, L. 1987. The molecular control of blood cell development. Science (Wash. DC). 238:1374-1379.

2. Metcalf, D. 1989. The molecular control of cell division, differentiation commitment and maturation in haemopoietic cells. Nature (Lond.). 339:27-30.

3. Fukunaga, R., I. E. Ikeda, Y. Seto, and S. Nagata. 1990. Expression cloning of a receptor for murine granulocyte colony-stimulating factor. Cell. 61:341-350.

4. Sherr, C. J. 1990 . Colony-stimulating factor-1 receptor. Blood. 75:1-12.

5. Bishop, J. M. 1991. Molecular themes in oncogenesis. Cell. 64:235-248.

6. Hunter, T. 1991. Cooperation between oncogenes. Cell. 64:249-270.

7. Cantley, L. C., K. R. Auger, C. Carpenter, B. Duckworth, A. Graziani, R. Kapeller, and S. Soltoff. 1991. Oncogenes and signal transduction. Cell. 64:281302.

8. Greenberg, M. E., and E. B. Ziff. 1984. Stimulation of 3T3 cells induces transcription of the c-fos proto-oncogene. Nature (Lond.). 311:433-438.

9. Cohen, D. R., and T. Curran. 1988. Fra-1: a serum-inducible, cellular immediate-early gene that encodes a fos-related antigen. Mol. Cell. Biol. 8:20632069.

10. Bohmann, D., T. J. Bos, A. Admon, T. Nishimura, P. K. Vogt, and R. Tjian. 1987. Human protooncogene c-jun encodes a DNA binding protein with structural and functional properties of transcription factor AP-1. Science (Wash. DC). 238:1386-1392.

11. Ryseck, R. P., S. I. Hirai, M. Yaniv, and R. Bravo. 1988. Transcriptional activation of c-jun during the $G_{0} / G_{1}$ transition in mouse fibroblasts. Nature (Lond.). 334:535-537.

12. Lamph, W. W., P. Wamsley, P. Sassone-Corsi, and I. M. Verma. 1988. Induction of proto-oncogene JUN/AP-1 by serum and TPA. Nature (Lond.). 334:629-631.

13. Angel, P., E. A. Allegretto, S. Okino, K. Hattori, W. J. Boyle, T. Hunter, and $M$. Karin. 1988. Oncogene jun encodes a sequence-specific transactivator similar to AP-1. Nature (Lond.). 332:166-171.

14. Ryder, K., L. F. Lau, and D. Nathan. 1988. A gene activated by growth factors is related to the oncogene v-jun. Proc. Natl. Acad. Sci. USA. 85:14871491.

15. Ryder, K., A. Lanahan, E. Perez-Albuerne, and D. Nathan. 1989. Jun-D: a third member of the Jun gene family. Proc. Natl. Acad. Sci. USA. 86:15001503. 
16. Hirai, S. I., R. P. Ryseck, F. Mechta, R. Bravo, and M. Yaniv. 1989. Characterization of junD: a new member of the jun proto-oncogene family. EMBO (Eur. Mol. Biol. Organ.) J. 8:1433-1439.

17. Nomura, N., M. Ide, S. Sasamoto, M. Matsui, T. Date, and R. Ishizaki. 1990. Isolation of human CDNA clones of jun-related genes, jun-B and jun-D. Nucleic Acids Res. 18:3047-3048.

18. Pertovaara, L., L. Sistonen, T. J. Bos, P. K. Vogt, J. Keski-Oja, and K. Alitalo. 1989. Enhanced jun gene expression is an early genomic response to transforming growth factor $\beta$ stimulation. Mol. Cell. Biol. 9:1255-1262.

19. Nakamura, T., R. Datta, S. Kharbanda, and D. Kufe. 1991. Regulation of jun and fos gene expression in human monocytes by the macrophage colonystimulating factor. Cell Growth \& Differ. 2:267-272.

20. Chiu, R., P. Angel, and M. Karin. 1989. JunB differs in its biological properties from, and is a negative regulator of, c-jun. Cell. 59:979-986.

21. Schutte, J., J. Viallet, M. Nau, S. Segal, J. Fedorko, and J. Minna. 1989. Jun-B inhibits and c-fos stimulates the transforming and transactivating activities of c-jun. Cell. 59:987-997.

22. Kataoka, T., Y. Morishita, M. Ogura, Y. Morishima, M. Towatari, Y. Kato, H. Inoue, and H. Saito. 1990. A novel human myeloid leukemia cell line, NKM-1, coexpressing granulocyte colony-stimulating factor receptors and macrophage colony-stimulating factor receptors. Cancer Res. 50:7703-7709.

23. Morishita, Y., T. Kataoka, M. Towatari, T. Ito, H. Inoue, M. Ogura, Y. Morishima, and H. Saito. 1990. Up-regulation of transferrin receptor gene expression by granulocyte colony-stimulating factor in human myeloid leukemia cells. Cancer Res. 50:7955-7961.

24. Mosmann, T. 1983. Rapid colorimetric assay for cellular growth and survival: application to proliferation and cytotoxicity assays. J. Immunol. Methods. 65:55-63.

25. Chirgwin, J. M., A. E. Przybyla, R. J. MacDonald, and W. J. Rutter. 1979.
Isolation of biologically active ribonucleic acid from sources enriched in ribonuclease. Biochemistry. 18:5294-5299.

26. Chomczynski, P., and N. Sacchi. 1987. Single step method of RNA isolation by acid guanidium thiocyanate-phenol-chloroform extraction. Anal. Biochem. 162:156-159.

27. Sassone-Corsi, P., L. J. Ransone, W. W. Lamph, and I. M. Verma. 1988 Direct interaction between fos and jun nuclear oncoproteins: role of the leucine zipper' domain. Nature (Lond.). 336:692-695.

28. Kouzarides, T., and E. Ziff. 1989. Leucine zippers of fos, jun and GCN4 dictate dimerization specificity and thereby control DNA binding. Nature (Lond.). 340:568-571.

29. Nakabeppu, Y., K. Ryder, and D. Nathan. 1988. DNA binding activities of three murine jun proteins: stimulation by Fos. Cell. 55:907-915.

30. Datta, R., M. L. Sherman, R. M. Stone, and D. Kufe. 1991. Expression of the jun-B gene during induction of monocytic differentiation. Cell Growth \& Differ. 2:43-49.

31. Roussel, M. F., S. A. Shurtleff, J. R. Downing, and C. J. Sherr. 1990. A point mutation at tyrosine-809 in the human colony-stimulating factor 1 receptor impairs mitogenesis without abrogating tyrosine kinase activity, association with phosphatidylinositol 3-kinase, or induction of c-fos and junB genes. Proc. Natl. Acad. Sci. USA. 87:6738-6742.

32. Roussel, M. F., J. L. Cleveland, S. A. Shurtleff, and C. J. Sherr. 1991. Myc rescue of a mutant CSF-1 receptor impaired in mitogenic signalling. Nature (Lond.). 353:361-363.

33. Kovary, K., and R. Bravo. 1991. The Jun and Fos protein families are both required for cell cycle progression in fibroblasts. Mol. Cell. Biol. 11:44664472.

34. Carter, R., S. C. Cosenza, A. Pena, K. Lipson, D. R. Soprano, and K. J. Soprano. 1991. A potential role for c-jun in cell cycle progression through late $G_{1}$ and S. Oncogene. 6:229-235. 